\title{
Wybrane problemy holistycznej edukacji środowiskowej w świetle idei zrównoważonego rozwoju
}

Sposób podejścia do problematyki metodyki w holistycznej edukacji środowiskowej, uzależniony jest $\mathrm{w}$ dużej mierze od autorów podejmujących ten temat. Widać tutaj merytoryczną zbieżność, jaka istnieje w dość wieloznacznym podejściu do samej edukacji środowiskowej, jak i pojęcia „świadomości ekologicznej" ${ }^{\prime}$. Zarówno w jednym, jak i w drugim przypadku metodyka zdominowana jest przez przedmiot i metodologię badań dyscyplin naukowych, podejmujących tę problematykę. Trudno jest zresztą mówić o spójnej metodyce, wtedy kiedy przedmiotem badań są tak odrębne elementy, jak z jednej strony wiedza empiryczna o zjawiskach i procesach zachodzących w środowisku przyrodniczym, a z drugiej idee, czy też wartości opisujące środowisko i miejsce, jakie w nim zajmuje człowiek. Koncepcja idei zrównoważonego rozwoju, po raz pierwszy spowodowała, konieczność nowego spojrzenia również na problemy w obszarze wspomnianej metodyki badawczej. Nie ma możliwości skutecznego rozwijania „świadomości ekologicznej” bez równoległego rozwoju nauk badających zjawiska przyrodnicze. Rozwój ten, powinien jednak się odbywać przy wyraźnej stymulacji płynącej z filozoficznego podejścia do świadomości ekologicznej, jako części świadomości społecznej. Sama „świadomość ekologiczna” do dziś, nie doczekała się zdefiniowanej ostatecznie kategorii socjologicznej. Dodatkowym problemem we wszelkiego typu analizach jest również zdefiniowanie platformy odniesienia dla świadomości ekologicznej. Czy będzie to świadomość jednostki, czy też grupy społecznej? Ponieważ „świadomość ekologiczna” jest w wymiarze jednostkowym w pewnym stopniu rezultatem procesu socjalizacji, należałoby więc badać indywidualną świadomość ekologiczną poszczególnych osób.

„Świadomość ekologiczna” ma również stanowić podstawowy element kategoryzujący dla koncepcji idei zrównoważonego rozwoju. Sposób, w jaki będzie

1 A. PApUZIŃsKi, Świadomość ekologiczna w świetle teorii i praktyki, Problemy Ekorozwoju, Lublin, vol. 1, Nr 1, s. 33-40, 2006. 
prowadzona ta kategoryzacja, uzależniony jest od procesu edukacji środowiskowej. Zdefiniowanie spójnej metodologii, opierającej się na jak najszerszym, interdyscyplinarnym podejściu do elementów środowiska przyrodniczego jest kluczowe w kształtowaniu procesu edukacji środowiskowej. Potrzeba holistycznego podejścia jest już coraz powszechniej akceptowana, ale nie zawsze tak samo rozumiana, przez różne grupy badaczy. Na poziomie tworzenia definicji, mniej lub bardziej holistycznych, nie skutkuje to większymi problemami. Inaczej jest w momencie, kiedy należy stworzyć zamkniętą metodykę badawczą, opierającą się na konkretnych rozwiązaniach holistycznych. W tym momencie dochodzi już do wielu nieporozumień prowadzących do konfliktów w efekcie blokujących rozwój podstaw naukowych dla idei zrównoważonego rozwoju. Konsekwencją tego procesu jest nie tylko trudność w rozumieniu współcześnie zachodzących zjawisk środowiskowych, ale również ich kształtowanie w myśl idei zrównoważonego rozwoju. Poprzez kształtowanie $\mathrm{w}$ tym wypadku, należy rozumieć zarządzanie nimi, doprowadzając do daleko idącej równowagi pomiędzy naturą, a człowiekiem. Proces zarządzania środowiskiem, wyłania się nam jako konsekwencja idei zrównoważonego rozwoju. Nie ma możliwości samodzielnego rozwoju idei zrównoważonego rozwoju, bez podejmowania równolegle świadomych działań w kierunku systemowych metod wdrażania zarządzania środowiskiem przyrodniczym. Proces zarządzania środowiskiem przyrodniczym jest natomiast, uzależniony od postępu w holistycznej edukacji środowiskowej. ${ }^{2}$ Wszystkie te powiązania świadczą o istotnym skomplikowaniu, całego tego procesu. Dopóki poruszamy się w sferze idei, można formułować dość spójne zamknięte modele środowiskowe. Inaczej jednak wygląda sytuacja w momencie, kiedy trzeba te dotychczas teoretycznie funkcjonujące modele środowiskowe, dostosować do konkretnych oczekiwań potencjalnych użytkowników (jednostek, czy grup społecznych). Jest to problem, który nie tylko dotyczy metodyki konkretnych rozwiązań środowiskowych, ale również procesu edukacji środowiskowej. Analizując procesy środowiskowe, które zachodzą w skali globalnej, należy również badać w podobnej skali. Wymusza to nowe jakościowo podejście do środowiska, bynajmniej jednak, nie zrywające z przyjętą metodyką badawczą obowiązującą w naukach przyrodniczych.

Głównym zamierzeniem twórców idei zrównoważonego rozwoju, była ochrona zasobów biotycznych. W okresie, kiedy powstawały idee zrównoważonego rozwoju, nauki przyrodnicze przechodziły szczególny moment rozwoju. Dyscypliny te w pewnym sensie na nowo definiowały swój warsztat badawczy. Warsztat, który bynajmniej nie opierał się na innej treści przedstawianych twierdzeń, lecz na przyjmowanych metodach, dzięki którym wyjaśniano te twierdze-

2 J. SANDNER, Wybrane aspekty procesów środowiskowych holistycznej edukacji przyrodniczej w świetle idei zrównoważonego rozwoju, Problemy Ekorozwoju, vol. 3, Nr 2, s. 69-80, 2008. 
nia. Określenie prawidłowych zasad, w oparciu o które budowano metodykę badawczą, stało się podstawą wiedzy naukowej, na której można było budować różne idee, między innymi ideę zrównoważonego rozwoju. Na szczególną uwagę, zasługuje tutaj zasada brzytwy Occama, po raz pierwszy sformułowana przez angielskiego średniowiecznego teologa Williama Occama. ${ }^{3}$ Badacz ten zauważył, że do objaśniania rzeczywistości, nie trzeba używać większej ilości niezależnych bytów, niż to jest konieczne. Zasada ta w swojej strukturze, nie tylko definiowała potrzebę zmniejszenia opisywanych bytów w postaci praw przyrody, ale również sugerowała możliwość łączenia tych praw, lub scalania $\mathrm{w}$ tzw. prawa uniwersalne. Tworzenie praw, powstałych w wyniku takiego procesu łączenia, stanowi istotny moment postępu w rozwoju danej dziedziny nauki. Rozwój nauk przyrodniczych w momencie tworzenia się idei zrównoważonego rozwoju, nie do końca jednak uwzględniał zasadę Occama.

W tym czasie jednak w dalszym ciągu wielu naukowców, badających przyrodę $\mathrm{w}$ sposób świadomy wybierało drogę poznania naukowego przyrody na drodze znacznie bardziej złożonej. Nie zawsze jednak droga ta, była w pełni uzasadniona naukowo. Naukowcom, którzy badali procesy fizykochemiczne, czy biologiczne wytłumaczenie wyboru, tej bardziej złożonej drogi naukowej, przychodziło zawsze znacznie łatwiej. O tyle naukowcom, badającym zjawiska z udziałem czynnika czasu i przestrzeni tłumaczenie takie nastręczało istotne merytoryczne trudności. Do tej ostatniej grupy, zaliczają się między innymi: ekolodzy, paleontolodzy, czy sedymentolodzy. W swojej interpretacji praw przyrody, potrzebują oni nowego wymiaru w postaci czasu i przestrzeni. Dlatego też ten swoisty ,jednowymiarowy” obraz Świata, który wystarczał takim grupom badaczy, jak fizykochemicy, stał się istotnym ograniczeniem dla tych drugich. Dla tej grupy okazało się, że liczne prawa przyrodnicze, mają zakres stosowalności ograniczony zarówno w czasie, jak i w przestrzeni. Poza danymi granicami są zastępowane przez inne prawa, które znów mają swój zdefiniowany zasięg w określonej czasoprzestrzeni.

Zasadę Occama, należy stosować również do tych teorii budowanych w oparciu o wymiar czasu i przestrzeni. Problemy w stosowaniu przez naukowców, między innymi: ekologów zasady Occama w okresie tworzenia (na początku lat 80-tych) idei zrównoważonego rozwoju, wywarło pewne piętno w rozumieniu środowiska przyrodniczego. ${ }^{4}$

Wszelkie prawa przyrody, działające współcześnie z pewnością funkcjonowały również w przeszłości. Zasada ta najbardziej znana pod hasłem aktualizmu geologicznego, lub uniformitarianizmu, stała się prawdopodobnie podstawą w in-

J. DzıK, Dzieje życia na Ziemi, Wprowadzenie do paleobiologii, PWN, Warszawa, s. 523, 2003.

4 J. SANDner, Idea zrównoważonego rozwoju $w$ holistycznej edukacji przyrodniczej, Problemy Ekorozwoju, Lublin, vol. 2, Nr 2, s. 103-107, 2007. 
terpretacji idei zrównoważonego rozwoju, a zarazem rozumieniu otaczającego nas środowiska przyrodniczego. Jedną z zasad w idei zrównoważonego rozwoju jest takie gospodarowanie środowiskiem przyrodniczym i jego zasobami, aby przyszłe pokolenia mogły korzystać z tego środowiska w oparciu o te same, nie pomniejszone zasoby przyrodnicze. Oparcie idei zrównoważonego rozwoju na tej zasadzie, powoduje z punktu widzenia naukowego, wiele istotnych wątpliwości. Jeżeli idee te, mają opierać się na podstawach naukowych, to muszą podlegać tzw. zasadzie testowalności.

Powszechnie przyjętą regułą, określającą granice nauki jest wspomniana zasada testowalności teorii naukowych przez empirię. Idea zrównoważonego rozwoju w swojej istocie, stała się pewną teorią naukową, odnoszącą się do zdefiniowanego a priori przyszłego obrazu środowiska przyrodniczego. Idea ta, obudowana została wieloma „teoriami naukowymi”, które z punktu widzenia celu, jaki mają spełniać są jednak z góry sprzeczne z empirią. Dlatego też, nie mogą służyć, jako wiarygodny materiał naukowy. Opieranie idei zrównoważonego rozwoju na tego typu wnioskowaniu dedukcyjnym jest w pewnym sensie błędne i z pewnością, nie prowadzi nas do naukowego poznania przyrody. Jak wiadomo teorie, w których wniosków, nie można testować empirycznie są pozbawione naukowych podstaw.

Tworzenie podstaw naukowych dla idei zrównoważonego rozwoju, oparło się więc częściowo na predykcji, czyli przewidywaniu przyszłego stanu środowiska przyrodniczego, wnioskując na podstawie znajomości jego obecnego stanu i rządzących jego przekształceniami praw. Rozwiązanie to $\mathrm{z}$ naukowego punktu widzenia, okazuje się jednak również w pewnym sensie ułomne i w wielu przypadkach, po prostu się nie sprawdza. Niedoskonałość tego rozwiązania polega na tym, że nie zawsze można przewidzieć przyszłe zmiany środowiska przyrodniczego. Tak jak z tych samych przyczyn, nie można dzisiaj również przewidzieć dalszego przebiegu ewolucji na Ziemi.

Ilość procesów, systemów i nieprzewidywalnych interakcji środowiskowych, daje nam raczej dość iluzoryczne wrażenie w zakresie budowania teorii naukowych, tym razem testowanych w oparciu o retrodykcję, czy inaczej postdykcję.

Inną naukową barierą stwarzającą poważne problemy poznania przyrodniczego jest tzw. teoria poziomów integracji. Teoria ta głosi, że nie można przewidzieć właściwości wyższego poziomu, znając tylko właściwości niższego poziomu. Nie można przewidzieć właściwości wody, znając jedynie właściwości wodoru i tlenu, nie można przewidzieć cech ekosystemów na podstawie znajomości cech izolowanych populacji. Ma to daleko idące konsekwencje w budowaniu, przede wszystkim poznania naukowego środowiska przyrodniczego, które ciągle skupia się na tych najniższych poziomach integracji. Wynika to między innymi z faktu, że nauki zajmujące się tymi wyższymi poziomami organizacji biologicznej, jak np. Ekologia wydzieliły się stosunkowo późno z biologii, dla 
której głównymi dziedzinami zainteresowania, były takie podstawowe dziedziny badań, jak: biologia molekularna, biologia rozwoju, genetyka, czy działy taksonomiczne, jak: bakteriologia, botanika, czy entomologia. Wspomniane dziedziny nauk biologicznych, całkowicie skupiły się na rozwiązywaniu problemów na poziomie tzw. podstawowym, to znaczy: związków chemicznych, organelli wewnątrzkomórkowych, komórki, tkanki, narządów, układów narządów, skończywszy wreszcie na organizmie. ${ }^{5}$ Daleko idąca niechęć do rozwiązywania problemów z wyższych poziomów organizacji biologicznej, polegała przez długi czas przede wszystkim na trudnościach empirycznych. Trudności te, zostały przełamane wraz z rozwojem ekologii, dla której głównym punktem zainteresowania, były kolejne poziomy organizacji biologicznej.

Ekologia zajęła się dziedzinami organizacji biologicznej, które dotychczas były praktycznie nieznane. Uruchomione zostały badania na poziomie populacji, zespołu ekologicznego, czy ekosystemu. Oczywiście i w tym przypadku poziom poznania naukowego jest ściśle dostosowany do poziomu organizacji biologicznej. W miarę wzrostu poziomu organizacji biologicznej, wyraźnie maleje poziom poznania naukowego. Współzależność ta ma bardzo istotny wpływ w konstruowaniu idei zrównoważonego rozwoju. Wypracowując podstawy naukowe dla tej idei, korzystać powinno się przede wszystkim z osiągnięć nauki na tych najwyższych poziomach organizacji biologicznej, które są jednak najmniej poznane naukowo. Wynika to również $\mathrm{z}$ faktu zaniedbywania w rozwoju naukowego poznania przyrody, podejścia holistycznego. Podejście holistyczne, zapisało się w sposób dość naturalny już w samych podstawach ekologii. Bo czym była tzw. „historia naturalna”, polegająca na opisywaniu całych formacji roślinnych występujących na Ziemi oraz związanymi z nimi funkcjonalnie gatunków zwierząt. Pozostałe kierunki ekologii, które się z niej wyodrębniły również mają wyraźne holistyczne podejście w budowaniu swojego warsztatu naukowego. Dotyczy to zarówno ekologii funkcjonalnej, jak i ewolucyjnej. Dlatego trudno jest dziś do końca zrozumieć, dlaczego tworząc merytoryczne podwaliny dla idei zrównoważonego rozwoju, podejście do środowiska było bynajmniej, nie holistyczne. Skupienie się przede wszystkim na środowisku biotycznym spowodowało daleko idące konsekwencje dla kondycji wielu ekosystemów. Skutki wielu błędnych decyzji z tamtych czasów są widoczne do dzisiaj, którym dali wyraz Austriacy w pierwszej połowie roku 2006, kiedy to przewodniczyli UE. Niedocenianie przez długi czas roli, jaką pełni również środowisko abiotyczne, było jednym z błędów w tworzeniu koncepcji idei zrównoważonego rozwoju. Bez biotopu, nie ma ekosystemu. Analizując historię powstawania pojęcia biotopu w ekologii, ten sam błąd popełniono w konstruowaniu idei koncepcji zrównoważonego rozwoju. W ekologii, musiało upłynąć kilkadziesiąt lat, kiedy to zrozumiano, że powią-

J.B. Harborne, Ekologia biochemiczna, Wydawnictwo PWN, Warszawa, s. 351, 1997. 
zania troficzne dotyczą nie tylko organizmów tworzących biocenozę, ale w nie mniejszym stopniu również dotyczą martwego środowiska biocenozy. To martwe środowisko z czasem, nazwano właśnie biotopem, a w 1935 Tansley mógł po raz pierwszy wprowadzić pojęcie ekosystemu. Ekosystem jako taki, nie stał się od razu jednak podmiotem, czy punktem odniesienia w idei zrównoważonego rozwoju. Brak wystarczającego zrozumienia dla problematyki abiotycznej jest w koncepcji tej praktycznie widoczny do dzisiaj. Wynika on prawdopodobnie Z wielu przyczyn. $Z$ jednej strony są to przyczyny natury czysto ekologicznej, $\mathrm{z}$ drugiej z powodu wielowymiarowości rozwoju zrównoważonego. W swojej naturze ekologicznej, poszukiwano układu odniesienia w środowisku, który jest układem najbardziej samowystarczalnym pod względem chociażby przepływu materii i energii. Układem tym niewątpliwie jest biosfera. Dlatego też właśnie biosfera stała się tym układem odniesienia ze wszelkimi tego konsekwencjami.

Budując idee zrównoważonego rozwoju w oparciu o ten układ, łatwo było wprowadzać określone postulaty, jednakże ze względu na bardzo niski poziom poznania naukowego, tego układu oraz problemy w zakresie empirii, wszelkie głoszone teorie $\mathrm{w}$ ramach zrównoważonego rozwoju, pozostały w sferze daleko idących domniemań i nie popartych naukowymi wywodami koncepcjami. Jest to w pewnym sensie zrozumiałe z punktu widzenia ogólnych założeń dla tej koncepcji. Trudno jest w niej definiować zadania dla ekosystemów w momencie, gdy tworzymy koncepcję o charakterze ponadnarodowym. Koncepcję, w której odnosimy się do zasobów całej Ziemi, w tym całej ludzkości obecnie ją zamieszkującej, a także przyszłych pokoleń. Tworząc tak szeroko sformułowaną koncepcję praktycznie nie ma możliwości, aby mogła ona się opierać na solidnych podstawach naukowego poznania przyrody. Do tego dochodzi jej wielowymiarowość, która $\mathrm{z}$ jednej strony jest jej siłą, $\mathrm{z}$ drugiej powoduje dodatkowe wewnętrzne konflikty merytoryczne na poszczególnych płaszczyznach odniesienia. ${ }^{6}$ Konflikty polegające, między innymi na różnym rozumieniu, tych samych pojęć naukowych. Nie można w jednej idei o charakterze niewątpliwie naukowym, łączyć problematyki z tak odległych dyscyplin, jaką jest technika, moralność, ekonomia, prawo, czy wreszcie polityka.

W kształtowaniu koncepcji zrównoważonego rozwoju, bardzo istotne jest podłoże filozoficzne. To właśnie ekofilozofia przeciwstawia się dominującym dotychczas poglądom, opierających się na antropocentryzmie. Wiara w nieograniczone możliwości człowieka, niczym nieskrępowane korzystanie z zasobów środowiska, ustępuje nowym poglądom, w których człowiek staje się jedynie jednym z elementów biocenozy. W biocentrycznym podejściu człowiek i przyroda, powinny się rozwijać harmonijnie. Ten sposób myślenia stał się podstawą

6 A. PawŁowski, Wielowymiarowość rozwoju zrównoważonego, Problemy Ekorozwoju, vol. 1, Nr 1, s. 23-32, 2006. 
dla nowej filozofii, czy ekofilozofii. Ekofilozofii, w której daleko idąca symbioza, pomiędzy człowiekiem a środowiskiem, stała się również podstawą trwałego zrównoważonego rozwoju. Całkowita niezależność od zasobów środowiska, okazała się mitem. Prekursorami tego sposobu myślenia, było wielu filozofów. W większości wypadków ich sposób widzenia ekofilozofii wywodzi się z daleko idącej krytyki cywilizacji technicznej oraz prób jej przebudowywania. Z obecnej perspektywy jest dość trudno autorytatywnie stwierdzić, kto był faktycznym prekursorem nowego podejścia biocentrycznego do środowiska. Czy byli to filozofowie, coraz intensywniej podejmujący krytykę cywilizacji technicznej, czy ekolodzy? Niewątpliwie jednak, obydwa te nurty myślowe, dały w końcu asumpt pod projekt nowej rzeczywistości społeczno-politycznej, w której obok czynników ekonomicznych, należne miejsce znalazła wreszcie problematyka związana ze środowiskiem przyrodniczym. Ostatecznie stało się to możliwe, dzięki powołaniu programu zrównoważonego rozwoju, tym razem w wyniku świadomej decyzji polityków, którzy nadali temu projektowi właściwą rangę międzynarodową. Idea zrównoważonego rozwoju do dzisiejszego dnia, nie doczekała się precyzyjnej definicji naukowej. Jest to z pewnością spowodowane wieloma trudnościami natury, nie tylko merytorycznej. Jest to program, który z jednej strony spełnia pewne potrzeby polityczne, stanowiąc wygodne, a zarazem nośne medialnie narzędzie propagandowe. $Z$ drugiej jednak strony, istnieją bardzo poważne problemy w sferze naukowego poznania przyrody (o czym była już mowa wcześniej), stanowiące merytoryczną barierę dla kształtowania naukowego podłoża idei zrównoważonego rozwoju. Podłoża opierającego się na wspomnianej koncepcji biocentryzmu. Koncepcji przewartościowującej nasz stosunek do środowiska. Koncepcji, w której ekofilozofowie, definiują nową hierarchię wartości, dla której, powinny liczyć się przede wszystkim wszelkie wartości związane z biosferą, a nie jak dotychczas z wartościami świata ludzkiego.

Nie ma, możliwości dalszego rozwijania idei zrównoważonego rozwoju, bez prowadzenia równoległych badań naukowych $\mathrm{w}$ zakresie poznawania praw jakimi rządzi się środowisko. Badania te muszą mieć, nie tylko charakter badań holistycznych, tak aby spełniać potrzeby idei zrównoważonego rozwoju, ale również powinny opierać się na podstawowych zasadach nauki, tzn. empirii oraz „brzytwie Occama”. Nie zastosowanie się do tych wymogów spowoduje, że idee zrównoważonego rozwoju, pozostaną jedynie w sferze społeczno-politycznych dywagacji, stanowiąc w najlepszym przypadku, wygodne narzędzie wykorzystywane wyłącznie przez polityków. Holistyczne badania środowiska przyrodniczego z tych samych powodów, powinny również przełożyć się na proces edukacji środowiskowej. Punktem wyjścia w tworzeniu podstaw metodycznych dla holistycznej koncepcji edukacji środowiskowej stały się ekosystemy. W ten sposób kierunek badań w zakresie holistycznej edukacji środowiskowej oparty został, głównie na doświadczeniach zgromadzonych w ramach rozwoju jednej z naj- 
młodszych nauk ekologii. To właśnie Ekologia, jako pierwsza zwróciła uwagę na potrzebę holistycznego podejścia do rozumienia procesów środowiskowych. Dotychczas nasz model procesu edukacji przyrodniczej na rzecz ochrony środowiska, polegał właśnie na tym, że skoncentrowaliśmy się na badaniu i rozumieniu procesów składających się na tzw. części. W procesie tym, prawie całkowicie zapomniano o tzw. całości. Dopiero w metodach badawczych stosowanych w ekologii, zmieniono ten sposób myślenia.

W ekologii istnieją równolegle dwie podstawowe ekologiczne metody badawcze. Jedna z nich, została nazwana przez Forbes’a, jako mereologiczna od słowa gr. Meros - część, druga przez Birge’a od słowa gr. Holos - cały, jako holistyczna. Pierwsza z tych metod z powodzeniem rozwijała się wraz z postępem technologicznym i możliwościami badawczymi środowiska. Druga ze względu na swoją daleko idącą interdyscyplinarność i problemy metodyczne, ciągle napotyka na duże trudności. Obserwując rozwój nauk o środowisku, trudno byłoby wyjaśniać złożone hipotezy, bez wcześniejszego zebrania odpowiedniego „bagażu” wiedzy o naturze, czy też prawdziwej strukturze świata. Dlatego też podejście holistyczne stało się możliwe, dopiero w momencie, kiedy dysponowano już odpowiednią ilością obserwacji rzeczywistości przyrodniczej. Na tym podłożu, powstała teoria rozwoju zapoczątkowana przez J.Ch. Smutsa, propagowana przez niektórych biologów i filozofów angielskich na początku XX wieku. Teoria ta, odnosiła się do najważniejszego problemu merytorycznego związanego z prawidłową interpretacją rzeczywistości przyrodniczej. Głosiła ona, że całość nie da się sprowadzić do sumy części, a świat podlega ewolucji, w której toku wyłaniają się coraz to nowe całości. ${ }^{7}$ Teoria ta stała się podstawą do zrozumienia jednego z najważniejszych procesów w ekologii i ochronie środowiska, a mianowicie tzw. synergizmu.

Organizmy roślinne i zwierzęce rozwijają się pod ustawiczną presją czynników ekologicznych. W warunkach doświadczalnych w laboratorium, można badać wpływ każdego z tych czynników osobno. Inaczej dzieje się w warunkach naturalnych, gdzie jest to bardzo trudne, gdyż działają one razem, a efekt takiego działania $\mathrm{z}$ reguły jest odmienny od sumy oddziaływań poszczególnych czynników osobno. Zjawisko to właśnie jest synergizm. ${ }^{8}$ Pojęcie synergizmu rozwiązuje nam wiele problemów w rozumieniu środowiska przyrodniczego. Dotyczy to między innymi interakcji wzajemnego oddziaływania jonów, lub związków chemicznych w wyniku której, biologiczny efekt działania określonego pierwiastka jest uzależniony od występowania i stężenia innych jonów lub substancji chemicznych.

Wiele z tych interakcji, które zachodzą w środowisku charakteryzują się synergizmem. Zjawisko interakcji odgrywa istotną rolę, ponieważ często wywo-

J.C. Smuts, Holism and Evolution, Macmillan Co., New York, s. 192, 1926.

8 A. Mackenzie, A.S. Ball, S.R. Virdee, Ekologia; Instant Notes in Ecology, PWN, Warszawa, s. 396,2000 . 
łuje zaburzenia równowagi chemicznej w poszczególnych organizmach, a nawet w ekosystemie. Prowadzić to może w rezultacie do trudnych do przewidzenia konsekwencji w postaci: przyspieszenia, lub opóźnienia pewnych procesów biologicznych, zaburzeń genetycznych, zaburzeń procesu fotosyntezy, spadku produktywności, czy też włączania niektórych pierwiastków do łańcuchów troficznych. ${ }^{9}$

Na przykładzie reakcji synergizmu występującej w środowisku (efektu zwiększonego, który chcemy nie tylko monitorować, ale i rozpoznawać, a w miarę potrzeby również kontrolować), chyba najlepiej widać w jakim kierunku, powinny iść zmiany w konstruowaniu programów edukacji o środowisku przyrodniczym. Zmiany te w pierwszej kolejności, powinny dotyczyć uniwersyteckich kierunków, na których wykłada się przedmioty przyrodnicze. Przedmioty, które w zasadniczym stopniu decydują o wiedzy przyszłych absolwentów w zakresie środowiska przyrodniczego. Do przedmiotów tych należą, między innymi: Ekologia, Hydrologia, Gospodarka wodna, Geologia dynamiczna, Geomorfologia, Gleboznawstwo, Geologia złóż, Leśnictwo, Meteorologia, Toksykologia itp. Dotychczasowy system nauczania $\mathrm{w}$ żadnym razie, nie gwarantuje poznania przez studentów mechanizmów środowiskowych decydujących o faktycznej kondycji i jakości środowiska. Wiedza z wymienionych powyżej przedmiotów, najczęściej wykładana jest w ujęciu mereologicznym ze wszystkimi tego konsekwencjami. Konsekwencją w tym wypadku jest brak prawidłowego przygotowania absolwentów do zarządzania zasobami środowiska przyrodniczego.

Przygotowanie odpowiedniej metodyki nauczania o zasobach środowiska przyrodniczego, zgodnych z ideą edukacji holistycznej, staje się jednym z najważniejszych celów przed jakimi obecnie stoimy. Osiągnięcie tych celów jest niezbędne w świetle zadań, jakie są stawiane w ramach idei zrównoważonego rozwoju.

Z dotychczas przeprowadzonych badań wynika z pewnością, że głównym czynnikiem hamującym jest znikoma wiedza $\mathrm{z}$ zakresu rozumienia podstawowych pojęć środowiskowych oraz zachodzących w środowisku procesów. Brak naukowych opracowań, podejmujących metodykę holistycznej edukacji środowiskowej, przyczynia się również pośrednio do stanu świadomości pro-ekologicznej społeczeństw. Wypracowanie ujednoliconej metodyki w zakresie holistycznej edukacji środowiskowej, filozofii ekologicznej i etyki środowiskowej, powinno w efekcie wpłynąć, nie tylko na stan wiedzy w zakresie tej problematyki, ale również stworzyć $\mathrm{w}$ przyszłości merytoryczne podstawy do realizacji badań procesu kształtowania postaw pro-ekologicznych.

Metodyka ta powinna wyrastać ze stylu myślenia Aldo Leopolda (ojca filozofii ekologicznej i etyki środowiskowej) dla którego przyroda powinna być

A. MacioszczyK, D. DobrzyŃski, Hydrogeochemia, Wydawnictwo PWN, Warszawa, s. 448, 2007. 
traktowana, jako całość, a nie wybrane oderwane od siebie obszary. ${ }^{10}$ Powinna, być wartością samą $\mathrm{w}$ sobie $\mathrm{z}$ prawem do samodzielnego istnienia i trwania we właściwej sobie postaci, bez względu na potrzeby człowieka. Człowiek powinien ten stan w pełni uszanować, a co najważniejsze go respektować. System ochrony przyrody według Aldo Leopolda, nie powinien opierać się wyłącznie na korzyściach gospodarczych, ignorując $\mathrm{w}$ ten sposób inne elementy środowiska, nie mające walorów utylitarnych, a będące niezbędne dla prawidłowego funkcjonowania całości środowiska.

W idei zrównoważonego rozwoju, znacznie wyraźniej przebija się myślenie antropocentryczne. Wszystkie procesy środowiskowe, rozpatrywane są tutaj pod kątem potrzeb człowieka. Wśród tych procesów na pierwszy plan, wysuwają się wpływy antropogeniczne oraz kwestie dostępności zasobów Ziemskich dla przyszłych pokoleń. Takie podejście ogranicza kwestie etyczne do potrzeb człowieka. Ograniczoność takiego podejścia, nie sprzyja również budowaniu podstaw metodyki dla systemowej edukacji środowiskowej. System ten, nie powinien się wyłącznie opierać na przesłankach, czy określone działania w stosunku do środowiska przyrodniczego są dla niego korzystne, czy też nie są korzystne oraz, czy są zgodne z systemem norm, które chronią wyłącznie ludzkie prawa. Ograniczenia sformułowane w podejściu antropocentrycznym są widoczne w wielu dziedzinach działalności ludzkiej. Obecny stan wiedzy społeczeństw o środowisku przyrodniczym z pewnością ten proces pogłębia. Podejście antropocentryczne, które ciągle widoczne jest w wielu działaniach na rzecz edukacji środowiskowej, skutkuje konkretnymi konsekwencjami w dążeniu do jego pełnego poznania.

Nowe myślenie o środowisku przyrodniczym, wnosi ekologia głęboka. Niesie ona ze sobą tak zwaną erę „Zielonej polityki”, dla której głównym kierunkiem działania jest ochrona bogactwa i różnorodności. Ten sposób interpretacji i postrzegania środowiska przyrodniczego jest z pewnością dla niego korzystny. Umocowanie głównych zasad tego nurtu na wiedzy zaczerpniętej z ekologii z pewnością jest czynnikiem, który powoduje nowe spojrzenie na relacje środowiskowe, pomiędzy przyrodą a człowiekiem. W relacjach tych, zaczęto dostrzegać, potrzeby innych organizmów, ich rolę w systemie współzależności oddziaływania na siebie gatunków. Wśród filozofów, głównym propagatorem tego nurtu, był Norweg Arne Naess. ${ }^{11}$ Myśl ta, nie mogłaby powstać oraz dalej się rozwijać, bez istotnego udziału również wybitnych biologów, czy ekologów. Wielu z nich, dostrzegało głębokie relacje środowiskowe, pomiędzy człowiekiem a środowiskiem.

10 A. LeOPOLD, A sand county almanac and sketches here and there, 1949, przekład; Zapiski z piaszczystej krainy, przedmowa Okraska-Bystrak, Bielsko-Biała 2004, za W. TYBURski, Problemy Ekorozwoju nr 1, 2006.

11 A. NAess, Ecology, Community and Lifestyle, Wydawnictwo Cambridge University Press, s. 223, 1993. 
W latach siedemdziesiątych w naszym kraju, pomimo daleko idącym niesprzyjającym warunkom politycznym, jakie wtedy panowały, ukazało się kilka znaczących pozycji książkowych, podejmujących tę „niemile widzianą” problematykę. Jedną z najważniejszych z nich, była książka prof. dr. hab. Henryka Sandnera, pt. Człowiek i przyroda. ${ }^{12}$ Autor odważył się w niej wskazać na problemy harmonii i dysharmonii, między naturą i działalnością człowieka. Odniósł się również do narastającego, negatywnego wpływu cywilizacji technicznej na środowisko. Poruszył w niej, także problematykę relacji środowiskowych, ale od strony funkcjonowania łańcuchów troficznych. Ten sposób, postrzegania relacji środowiskowych z pewnością przyczynił się do dalszego rozwoju, nie tylko samej ekologii, ale również innych nauk, opierających swoje eksperymenty na podobnych założeniach metodycznych.

Podejście do metodyki holistycznej edukacji środowiskowej jest w pewnym sensie zbieżne z myśleniem holistycznym, reprezentowanym w ekologii głębokiej. Wspólną platformą dla tego podejścia jest przede wszystkim, już samo ujęcie holistyczne środowiska przyrodniczego. Zwolennicy, takiego podejścia wskazują, że jest to jedyna droga powstrzymania, postępującego globalnego kryzysu ekologicznego. Holistyczne podejście do tych problemów, powinno pomóc w budowaniu świadomości społecznej oraz ostatecznym odrzuceniu czysto technokratycznego podejścia do środowiska przyrodniczego. Kształtowanie świadomości proekologicznej, powinno oprzeć się na wiedzy w zakresie istnienia wzajemnych zwrotnych relacji środowiskowych. W tym wypadku bynajmniej jednak, nie powinno chodzić jedynie o układy opierające się na piramidzie troficznej, ale również pozostałych relacjach środowiskowych, dla których punktem odniesienia byłby ekosystem. Jest to rozwiązanie, które łączy w sobie nie tylko rezultaty badań opierających się na empirii, ale również wynikające z przemyśleń samej ekofilozofii. Rzecz toczy się przecież o naszą świadomość ekologiczną. Świadomość, na którą składa się koncepcja poznania świata, między innymi poprzez swoją interdyscyplinarność. Nabranie odpowiedniej perspektywy do tego podejścia, poprzez ujęcie procesów środowiskowych w systemie holistycznym jest najbliższe procesowi kształtowania świadomości ekologicznej. Bez świadomości ekologicznej, nie ma mowy, ani o wdrażaniu idei zrównoważonego rozwoju, jak i ich dalszym kształtowaniu w miarę, postępującego równolegle procesu, dalszej antropogenizacji środowiska przyrodniczego. Odwrócenie tych tendencji, możliwe jedynie będzie w momencie, gdy zostaną w naszej świadomości uruchomione wartości o odpowiedzialności za własne życie, a także życie przyszłych pokoleń oraz za środowisko w którym żyjemy, zgodnie z zasadą aksjologicznej etyki ekologicznej.

Według Skolimowskiego w myśl ewolucyjnego charakteru rzeczywistości głównym celem człowieka, nie powinna być bynajmniej chaotyczna eksploata-

12 H. SAndner, Człowiek i przyroda, Wiedza Powszechna, wyd. I, Warszawa, s. 273, 1972. 
cja wszystkich zasobów Ziemi, ale wręcz przeciwnie, rozumne działanie prowadzące do zachowania i wzmacniania tego wszystkiego, co istnieje. Ten sposób widzenia rzeczywistości, chyba najbardziej oddaje kierunek, w którym powinniśmy zmierzać, poszukując konkretnych rozwiązań dla metodyki edukacji środowiskowej. Jest to sposób widzenia środowiska, jego potrzeb, poprzez pryzmat holistycznych procesów środowiskowych w nim zachodzących. Dysponując tymi przemyśleniami oraz doświadczeniem, które wnieśli kolejni badacze tej problematyki, można powiedzieć, że zasadnicze kierunki dla samej myśli oraz roli jaką ma ona odegrać w kształtowaniu idei zrównoważonego rozwoju, nie ma już chyba nikt większych wątpliwości. Świadomość ekologiczną z pewnością należy kształtować, pozostaje jednak ciągle pytanie, jak od strony metodycznej, należy ten proces realizować? Jak od strony metodycznej potraktować, tak szeroką interdyscyplinarność tego zagadnienia? Gdzie, należałoby postawić granice dla poznania holistycznego, procesów odpowiedzialnych za przepływ energii i materii odbywający się w ramach ekosystemów? Wreszcie, jaką rolę, powinna odegrać ekofilozofia, jako element spójny w budowaniu idei zrównoważonego rozwoju?

Przytoczone pytania, stanowią jedynie wybrane przykłady problemów, przed którymi stoi nie tylko sama nauka, ale również społeczeństwa, które wcześniej czy później, będą musiały na nie odpowiedzieć, chcąc w dalszym ciągu skutecznie rozwijać idee zrównoważonego rozwoju. Rozwiązanie nawet niektórych zagadnień wchodzących w skład postawionych pytań, powinno być kontynuowane stopniowo w miarę rozwoju nauk podstawowych przyrodniczych o Ziemi oraz ekofilozofii. Prawdopodobnie, będzie to proces dość długotrwały, uzależniony, między innymi od postępów w procesie wdrażania holistycznego systemu edukacji środowiskowej.

Uruchomienie procesu wdrażania nowego systemu edukacji środowiskowej, nie będzie jednak możliwe bez wcześniejszego wypracowania właściwej metodologii oraz odpowiedniej metodyki badawczej. Metodyka ta, powinna umożliwiać przeprowadzenie dowolnych analiz uzyskiwanych efektów, realizowanego procesu kształcenia środowiskowego. Metodyka ta, nie tylko powinna być dostosowana do tego procesu, ale również co jest nie mniej ważne, powinna odpowiednio wyprzedzać cały proces konstruowania systemu holistycznej edukacji środowiskowej. Proces ten więc, nie powinien stanowić jedynie kolejnego zbioru założeń analitycznych, które nie będą mieć oparcia w żadnych praktycznych działaniach. Proces ten powinien mieć, jak najbardziej charakter konstruktywny. Filozofia skierowana ku ocaleniu, musi być filozofią konstruktywną, a nie tylko analizą. ${ }^{13}$ Musi przynieść również konkretne wymierne rezultaty w procesie kształtowania

13 H. SкоLıмоwsкi, Filozofia żyjąca. Ekofilozofia jako drzewo życia, Wydawnictwo Pusty Obłok, s. 106-110, 1993. 
świadomości ekologicznej. Jest to niezwykle ważne z punktu widzenia dalszego rozwijania idei zrównoważonego rozwoju. Brak holistycznego podejścia do edukacji skutkuje w rezultacie, nie tylko niskim stanem świadomości ekologicznej, ale również niemożnością badania wiedzy o środowisku odpowiedzialnej za ten stan.

\section{Bibliografia}

Dzıк J., Dzieje życia na Ziemi, Wprowadzenie do paleobiologii, PWN, Warszawa, s. 523, 2003.

Harborne J.B., Ekologia biochemiczna, Wydawnictwo PWN, Warszawa, s. 351, 1997.

LeOPold A., A sand county almanac and sketches here and there, 1949, przekład; Zapiski z piaszczystej krainy, przedmowa Okraska-Bystrak, Bielsko-Biała 2004, za Tyburski W., Problemy Ekorozwoju nr 1, 2006.

Macioszczyк A., Dobrzyński D., Hydrogeochemia, Wydawnictwo PWN, Warszawa, s. 448, 2007.

Mackenzie A., Ball A.S., Virdee S.R., Ekologia; Instant Notes in Ecology, PWN, Warszawa, s. $396,2000$.

Naess A., Ecology, Community and Lifestyle, Wydawnictwo Cambridge University Press, s. 223, 1993.

PAPUZIŃski A., Świadomość ekologiczna w świetle teorii i praktyki, Problemy Ekorozwoju, Lublin, vol. 1, Nr 1, s. 33-40, 2006.

Pawıowski A., Wielowymiarowość rozwoju zrównoważonego, Problemy Ekorozwoju, vol. 1, Nr 1, s. 23-32, 2006.

SAndner H., Człowiek i przyroda, Wiedza Powszechna, wyd. I, Warszawa, s. 273, 1972.

SANDNer J., Idea zrównoważonego rozwoju w holistycznej edukacji przyrodniczej, Problemy Ekorozwoju, Lublin, vol. 2, Nr 2, s. 103-107, 2007.

SANDNER J., Wybrane aspekty procesów środowiskowych holistycznej edukacji przyrodniczej w świetle idei zrównoważonego rozwoju, Problemy Ekorozwoju, vol. 3, Nr 2, s. 69-80, 2008.

Sкоцімошsкi H., Filozofia żyjąca. Ekofilozofia jako drzewo życia, Wydawnictwo Pusty Obłok, s. 106-110, 1993.

Smuts J.C., Holism and Evolution, Macmillan Co., New York, s. 192, 1926. 


\title{
Selected problems of environmental education in a holistic view of sustainable development
}

\author{
SUMMARY
}

The article is an attempt to define the problems of holistic thinking in terms of environmental education. Development of appropriate methodology in this matter, should ensure a better understanding of the environment, but also indicate the mistakes made so far in the process of environmental education.

All these activities should create a new quality in the issues of land management. This should lead to more effective crisis management in the natural environment on the ideals of sustainable development.

Preparation of appropriate methods of teaching about the resources of the natural environment, consistent with the idea of holistic education, becoming one of the most important goals we are currently facing. Achieving these objectives is necessary in light of the tasks that are put in the idea of sustainable development.

Develop a unified methodology for the holistic environmental education, environmental philosophy and environmental ethics, should ultimately affect not only the state of knowledge regarding these issues, but also create future substantive grounds for studies of the process of pro-environmental attitudes.

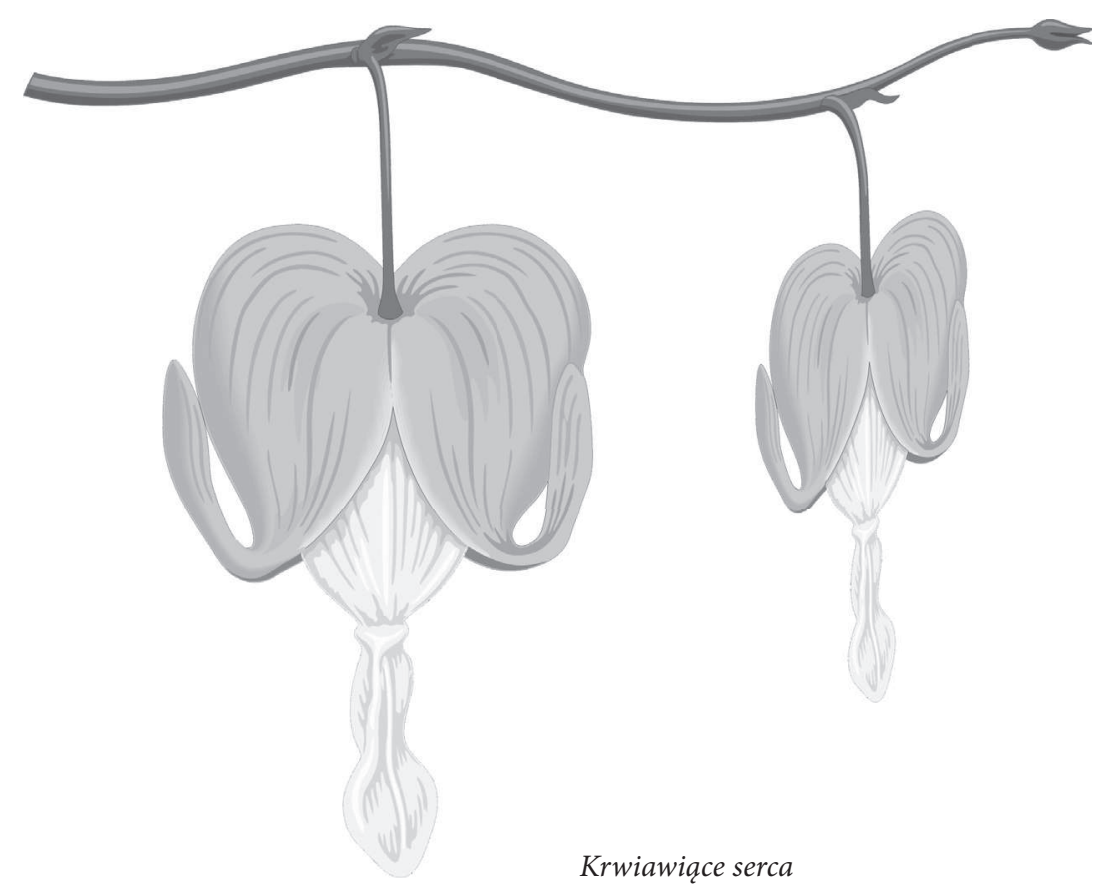

